\title{
Prediction of potato high-yield zones of a field: bivariate frequency ratio technique
}

\author{
Khalid A. Al-Gaadi ${ }^{1,2}$, Abdalhaleem A. Hassaballa ${ }^{1,3}$, \\ Rangaswamy Madugundu ${ }^{1, *}$, ElKamil Tola ${ }^{1,2}$ and Ronnel B. Fulleros ${ }^{2}$ \\ ${ }^{1}$ Precision Agriculture Research Chair, King Saud University, Riyadh, Saudi Arabia \\ ${ }^{2}$ Department of Agricultural Engineering, College of Food and Agriculture Sciences, King Saud University, Riyadh, Saudi Arabia \\ ${ }^{3}$ Department of Agricultural Engineering, Faculty of Engineering, University of Khartoum, Khartoum, Sudan
}

Bivariate frequency ratio (BFR) technique was employed to determine high-yield zones in a 30 ha potato (Solanum tuberosum L.) field located in WadiAd-Dawasir, Saudi Arabia. BFR was performed by inputting selected yield tendency factors (YTFs) and potato actual yield $\left(Y_{\mathrm{A}}\right)$. The YTFs were NDVIderived from Sentinel-2 images, soil electrical conductivity, nitrogen, $\mathrm{pH}$ and texture. The obtained yield tendency map $\left(Y_{\mathrm{P}}\right)$ was assessed against $Y_{\mathrm{A}}$ using the area under the curve metric. Although low accuracy (41-58\%) was observed with the individual YTFs, high-yield zones were determined with an accuracy of $\mathbf{9 0 \%}$ using the cumulative response of YTFs.

Keywords: Bivariate frequency ratio, potato field, soil parameters, yield prediction.

SPATIAL variation of crop productivity within a field is usually a result of soil properties and crop response. Identifying the most likely causes of crop yield variability and exploring the magnitude of variation within an agricultural field can greatly help in achieving effective site-specific management in accordance with agro-meteorological systems ${ }^{1-8}$. On the other hand, soil physico-chemical properties can vary within sub-metre scales ${ }^{9}$. Some studies have reported that variation in the concentration of soil properties within the field leads to spatial variability in crop yields ${ }^{10,11}$. Soil parameters such as soil electrical conductivity (EC), $\mathrm{pH}$, nutrients, compaction and bulk density are considered as major fluctuating yield tendency factors (YTFs) responsible for spatial variation of yield ${ }^{12-15}$. Previous studies have discussed management strategies for improving the resources and optimizing crop production $^{14-17}$.

The use of geo-spatial techniques in the assessment of yield spatial variability and its effect on crop yield has been well discussed ${ }^{6,18,19}$. Knowledge on the effect of YTFs, collectively and individually, on the performance of an agricultural crop can elucidate the reason for spatial variation in crop productivity ${ }^{20}$. A method that is proposed to assess yield tendency should be based on inde-

\footnotetext{
*For correspondence. (e-mail: rmadugundu@ksu.edu.sa)
}

pendent parameters that are correlated directly or indirectly with the spatial variation of crop yield ${ }^{21}$.

Bivariate analysis, a statistical analysis technique, helps in the quantitative assessment of susceptibility/ tendency of occurrence of events by calculating the weight of each individual class of event factors ${ }^{22,23}$. One of the most popular bivariate approaches is the frequency ratio $(\mathrm{FR})^{24}$, which has greater rigour compared to other bivariate techniques ${ }^{23,25}$. The area under the curve (AUC) is one of the most important metrics for evaluating the performance of any classification model ${ }^{26,27}$. Suzen and Vedat $^{28}$ succeeded in mapping the tendency by examining independent and dependent factors, and their contribution to bivariate frequency ratio (BFR) statistics.

The present study was aimed to (i) determine highyield tendency zones of a potato (Solanum tuberosum L.) field using the BFR technique by assessing the spatial correlation between selected YTFs and actual potato yield $\left(Y_{\mathrm{A}}\right)$, and (ii) assess the accuracy of the generated highyield tendency map using the AUC analysis tool.

\section{Study area}

The study was conducted on a 30 ha centre-pivot irrigated field in a farm belonging to the Saudi Agricultural Development Company, Wadi-Ad-Dawasir, Saudi Arabia, between $19.90^{\circ}$ and $20.33^{\circ} \mathrm{N}$ lat., and $44.81^{\circ}$ and $44.95^{\circ} \mathrm{E}$ long. (Figure 1). Temperature in the study site ranged from $6^{\circ} \mathrm{C}$ (winter) to $43^{\circ} \mathrm{C}$ (summer). The relative humidity was normally stable at $24 \%$, while average wind speed was $13 \mathrm{~km} / \mathrm{h}$ and the mean annual rainfall was about $37.6 \mathrm{~mm}$ (refs 29, 30). The major cultivated crops in the study farm were potatoes, maize, durum wheat, watermelon and alfalfa.

\section{Field data}

Potato crop was cultivated from November 2016 to March 2017 with a density of $4-5$ plants $/ \mathrm{m}^{2}$. The GPS (Trimble GeoXH 6000)-assisted soil samples and potato yield $\left(Y_{\mathrm{A}}\right)$ were collected from 120 sampling locations (Figure 1), 2-3 days prior to the harvest of potatoes. Sampling was performed for the entire experimental field 


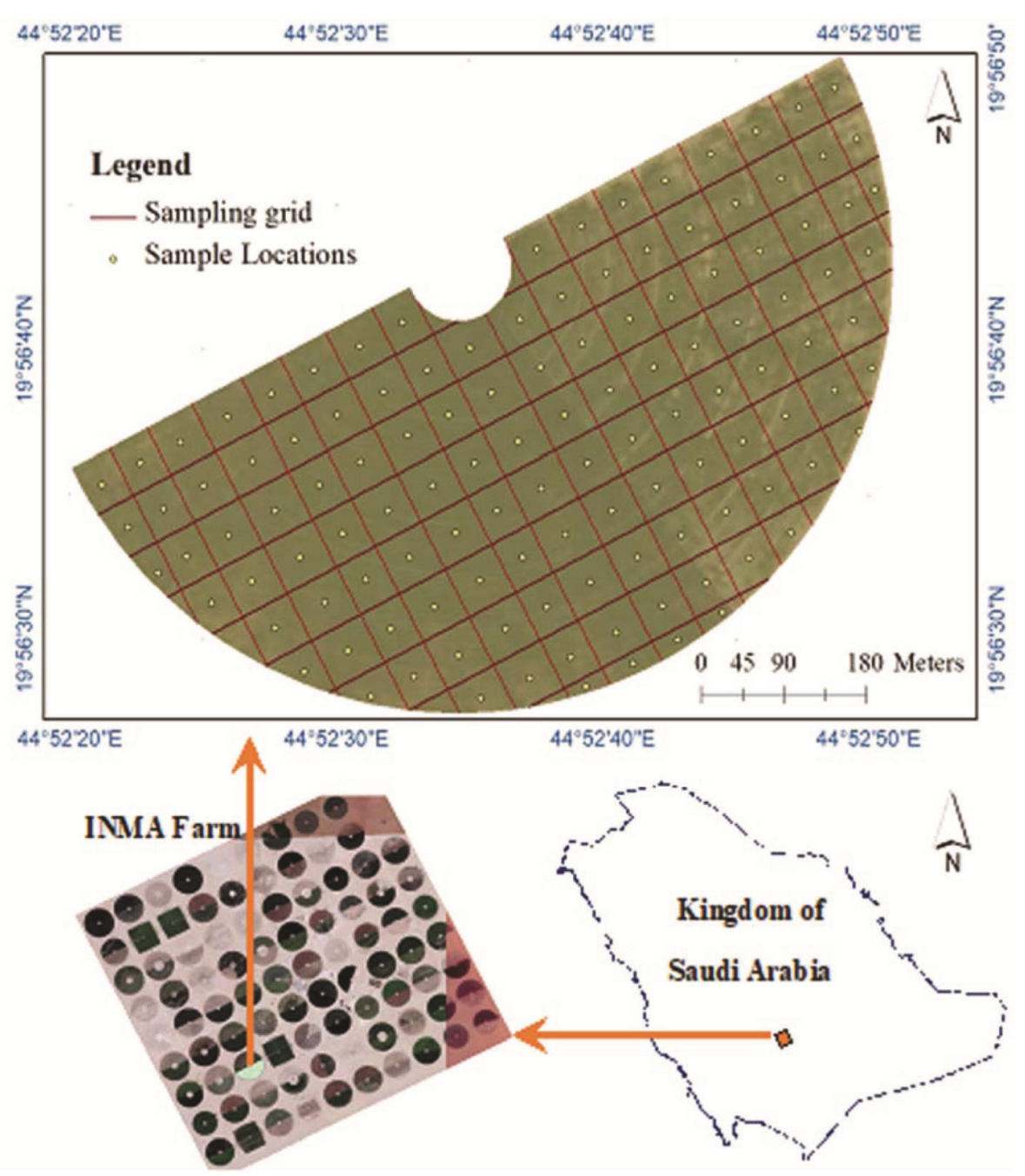

Figure 1. Location of experimental field overlaid by the sampling grids.

Table 1. Details of the sensor used and the images acquired

\begin{tabular}{lcc}
\hline Sensor & \multicolumn{1}{c}{ Date of pass } & Crop age (days) \\
\hline $\begin{array}{l}\text { Sentinel-2A-T38QMH } \\
\text { (orbit no. 49) }\end{array}$ & 17 December 2016 & 30 \\
& & \\
& 27 December 2016 & 40 \\
& 6 January 2017 & 50 \\
& 16 January 2017 & 60 \\
& 26 January 2017 & 70 \\
& 5 February 2017 & 80 \\
\hline
\end{tabular}

using a $50 \mathrm{~m} \times 50 \mathrm{~m}$ grid. Each sample consisted of five sub-samples (i.e. one from the centre of the grid and the remaining four from the corners of the grid at a distance of $15 \mathrm{~m})$. The soil samples $(0-15 \mathrm{~cm})$ were collected using a manual auger (SA6210C, with $62 \mathrm{~mm}$ bit diameter and $1.0 \mathrm{~m}$ steel rod length). In case of potato yield, potato tubers were harvested over an area of $3 \mathrm{sq} . \mathrm{m}$ at each sampling location. The collected potato samples were weighed (fresh weight) and converted to ordinary yield units (tonne/ha). Soil samples were air-dried, sieved and analysed for selected YTFs (soil nitrogen-N, pH, electrical conductivity (EC) and texture). The soil $\mathrm{N}$ content $(\mathrm{mg} / \mathrm{kg})$ was determined in the laboratory using the Kjeldahl method ${ }^{31}$, and soil $\mathrm{pH}$ and EC were measured using the $\mathrm{pH} /$ conductivity meter (Mi805). Soil texture was determined by the hydrometer method ${ }^{32}$.

\section{Satellite data and image analysis}

Six cloud-free Sentinel-2A images were downloaded from the USGS portal (https://earthexplorer.usgs.gov/) corresponding to potato cultivation (Table 1). The Q-GIS (Ver. 2.18) software was used to perform image analysis. Initially, Sentinal-2A images were pre-processed for atmospheric corrections, radiometric calibration and reflectance value calculation using the 'semi-automatic classification plugin (SCP)' module, and subsequently, the area of interest (i.e. experimental field) was extracted. Thereafter, normalized difference vegetation index (NDVI) was generated using band-4 ( $\rho$ RED) and band- $8(\rho$ NIR) of Sentinel-2A data $^{33}$. Multi-date NDVI layers were aggregated and the cumulative NDVI (CNDVI) was computed accordingly. 


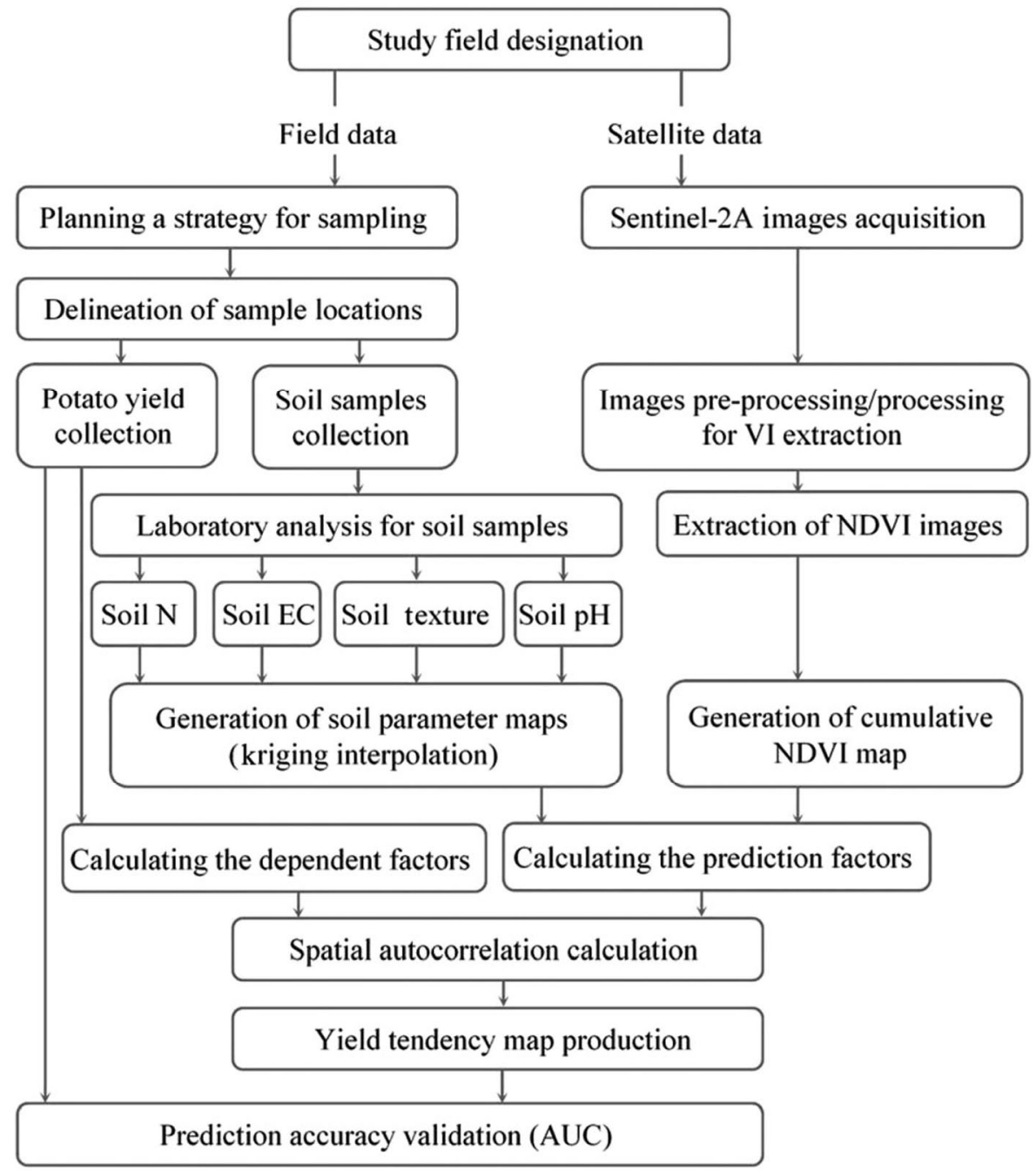

Figure 2. Yield tendency map and prediction accuracy assessment.

\section{Thematic data layers}

Surface models of YTFs (soil N, pH, EC and texture) and actual yield $\left(Y_{\mathrm{A}}\right)$ were tabulated along with their geo-referenced locations. Spatial analyst tool of the ArcGIS software was used in the preparation of surface models. Kriging interpolation method was adopted with Gaussian process governed by prior covariance to optimize the smoothness of the fitted values. The geospatial datasets (the multi-date NDVI, CNDVI, YTFs and $Y_{\mathrm{A}}$ ) were resampled to $10 \mathrm{~m}$ spatial resolution to generate the potato yield tendency $\left(Y_{\mathrm{P}}\right)$ map by employing BFR.

\section{Potato yield map - bivariate frequency ratio analysis}

In order to prepare the $Y_{\mathrm{P}}$ map, the BFR method was implemented using GIS techniques (Figure 2). For this,
$Y_{\mathrm{A}}$ was designated as a dependent factor and the studied YTFs (soil N, EC, pH, texture and NDVI) as independent variables (Figure 3). The generated surface model of $Y_{\mathrm{A}}$ was categorized into three zones (Figure 4). Potato yield ranging from 34 to 37 tonne/ha, was considered as 'low-yield zone' and 41 to 43 tonne/ha as 'high-yield zone'.

The frequency ratio (FR), relative frequency (RF) and prediction rate $(\mathrm{PR})$ coefficients were calculated for each of the studied YTFs. FR was computed as the percentage of occurrences in each sub-category to the percentage of the category (such as high, medium and low degrees in soil $\mathrm{pH}$ ) of the independent factors (eq. (1)). RF represents the weight of each FR to the total FR within the classes of a specific factor (eq. (2)). FR was based on the recorded associations between zoning of the event/ phenomenon and each associated factor which affects the occurrence of the event/phenomenon ${ }^{34}$. Furthermore, PR was used to assess the inter-relationships among the independent factors (eq. (3)). 

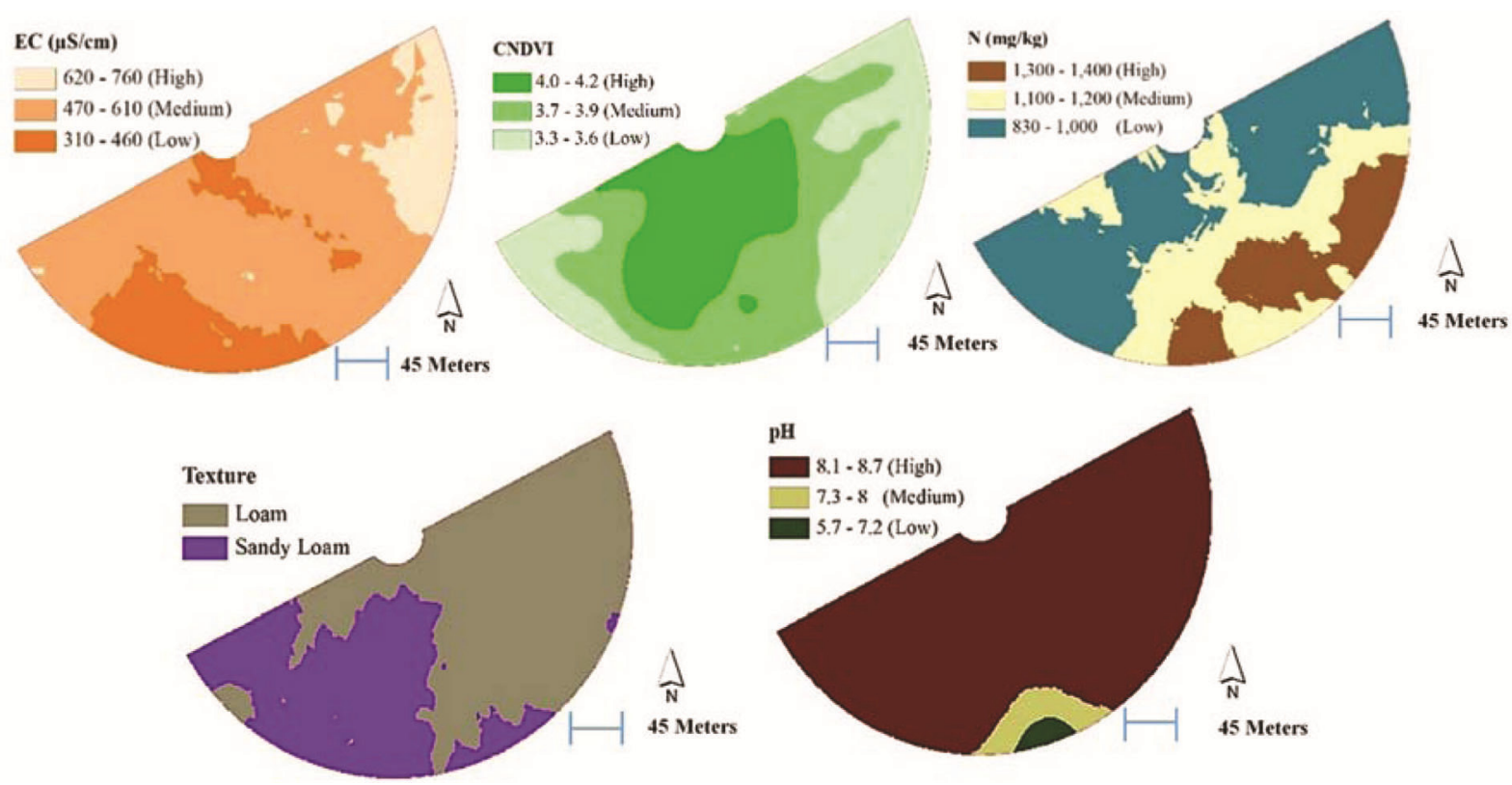

Figure 3. The independent variables (yield tendency factors) maps.

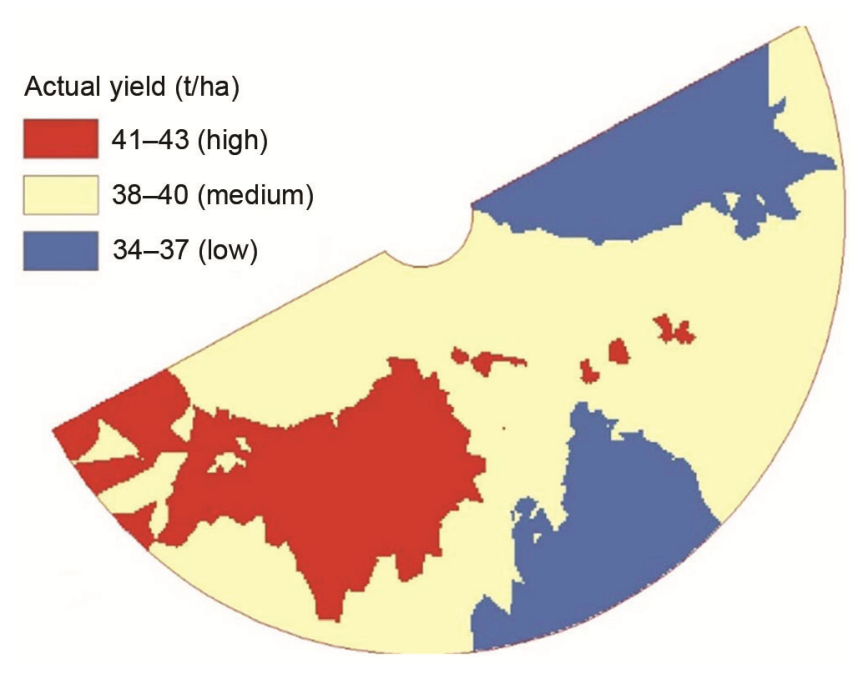

Figure 4. The actual yield $\left(Y_{\mathrm{A}}\right)$ map.

$$
\begin{aligned}
\mathrm{FR} & =\frac{\% \text { Target occurrence in each subcategory }}{\% \text { Category of an independent factor }} \\
& =\frac{\text { Points in factor } / \text { total points }}{\text { Factor class area/total area }}, \\
\mathrm{RF} & =\frac{\text { Factor class FR }}{\sum \text { Factor classes FR }} \\
\mathrm{PR} & =\frac{\mathrm{RF}_{\text {max }}-\mathrm{RF}_{\text {min }}}{\left(\mathrm{RF}_{\max }-\mathrm{RF}_{\min }\right)_{\min }},
\end{aligned}
$$

where FR is the frequency ratio, RF the relative frequency (index of the spatial association of YTFs and the targets, $\left.Y_{\mathrm{P}}\right)$ and $\mathrm{PR}$ is the predictor rate which is calculated as the ratio between the range and the minimum $R F$ value. The greater the FR, the more substantial is the relationship between occurrence and specific variables. For example, if FR is greater than 1, the relationship is strong, whereas it is weak if FR is less than 1, as described by Sujatha et $a l .{ }^{35}$.

A pairwise comparison (PW) was used as an additional method to compare PR generated from FR. Conditioning factors were tabulated horizontally and vertically, and then cross-divisions of PR were performed in order to examine the inter-relationship between each of the two factors. Eventually, PW comparison was generated as a summation of two YTFs with respect to the total ratio.

In order to generate the $Y_{\mathrm{P}}$ map, all the YTFs maps were reclassified based on the weight of each parameter class. The $Y_{\mathrm{P}}$ map was then generated (eqs (4) and (5)) as an accumulation of the resultant reclassified parameter maps multiplied by their relative PRs, as described in Althuwaynee et $a l{ }^{36}$.

$$
\mathrm{YTF}_{i}=\frac{\operatorname{Npix}_{(s i)}}{\sum_{i=1}^{n} \frac{N p i x_{(s i)}}{n}}
$$

where $\operatorname{Npix}_{(s i)}$ is the number of cells with crop yield in the $i$ th thematic class of a representative factor map and $n$ is the number of classes in the factor map.

$$
Y_{\mathrm{P}}=\mathrm{C}+\mathrm{N}+\mathrm{EC}+\mathrm{pH}+\mathrm{T},
$$

where $Y_{\mathrm{P}}$ is the predicted yield, and $\mathrm{C}, \mathrm{N}, \mathrm{EC}, \mathrm{pH}$ and $\mathrm{T}$ are weightage for CNDVI, nitrogen, soil $\mathrm{EC}$, soil $\mathrm{pH}$ and soil texture respectively. 
RESEARCH ARTICLES

Table 2. Statistical description of yield, soil parameters and CNDVI data

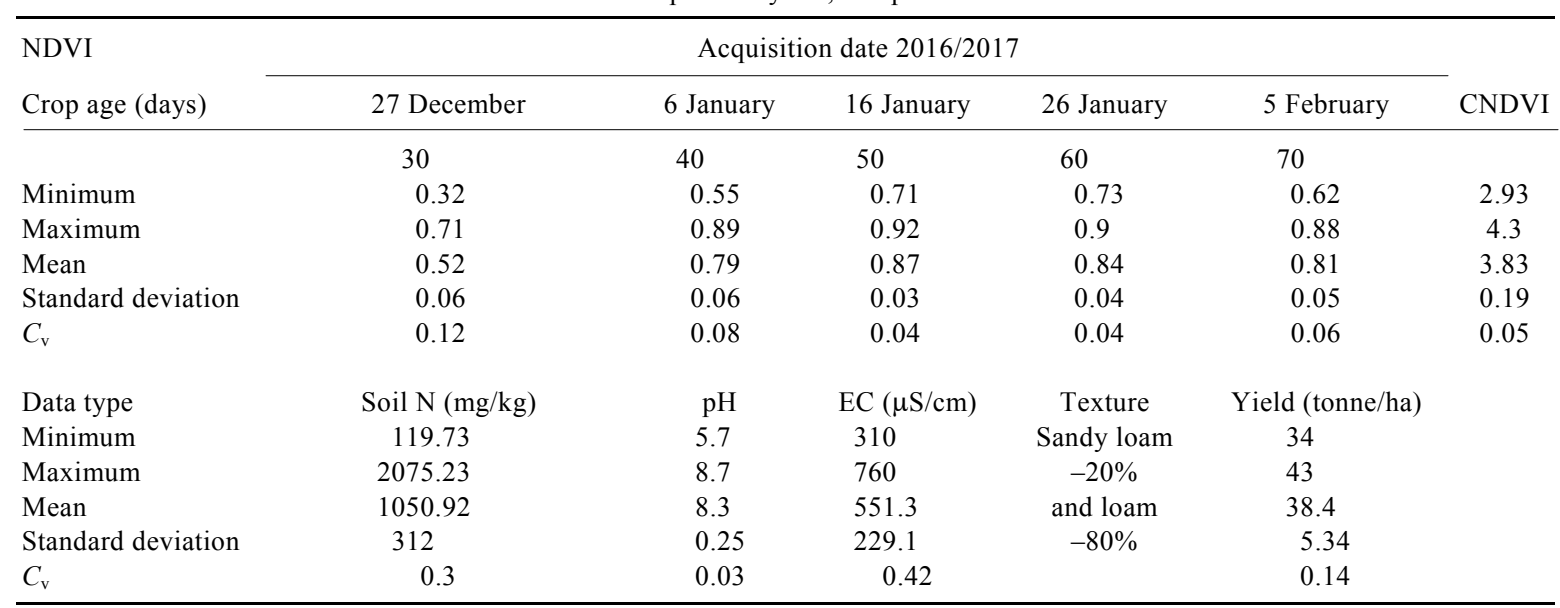

$C_{\mathrm{v}}$, Coefficient of variation; EC, Electrical conductivity.

The obtained $Y_{\mathrm{P}}$ map was classified and grouped into low, medium and high. The map was generated in raster format, in which three tendency levels of high yield were adopted, so as to avail suitable representation and comparison, namely high, medium and low tendency.

\section{Accuracy assessment}

As the present study aimed to assess YTFs with respect to high-yield zones, the area pertaining to 'high-yield zone' was extracted for further analysis. Hence, a total of 24 sampled locations pertaining to high-yield zone were isolated and randomly divided into two groups as training (60\%) and testing (40\%) sets, for accuracy assessment of BFR based on the generated high-yield zones of the $Y_{\mathrm{P}}$ map.

The AUC method was used to validate and assess the accuracy of the generated $Y_{\mathrm{P}}$ map, and to assure the capacity of each independent factor as a causative element with high yield occurrence. During the analysis, training and sample locations of potato yield were assessed. To obtain the relative ranks for each prediction pattern (independent factor maps), the calculated index values of all high-yield cells were sorted in descending order. Finally, AUC was calculated as percentage of the cumulative cell areas of common association. The percentage of AUC was then considered as an indicator of the FR model accuracy for the tendency to map potato high-yield zones. The study also intended to examine the association accuracy of each individual parameter as a controlling factor of high-yield occurrence. The produced sub-classes of the independent factor maps were reclassified and plotted against the high-yield points using AUC.

\section{Results and discussion}

Table 2 presents the descriptive statistics of the collected data. Obvious inter-relationships of soil parameters and yield values can be observed in the table, while there is no significant variability observed in the CNDVI values.

\section{Factor analysis}

In order to calculate RF, the number of points in each class was a result of spatial correlation between the highyield training points and independent factor map (Table 3 ). The percentage of each class point was calculated and class areas were estimated by summing each class pixel area; and finally the percentage of each class area was calculated. Subsequently, the RF was computed by dividing, the area of potato yield in one class with the total area of potato yield in all classes. As given in Table 3, individual YTFs and their association with the high-yield zone were found best at $\mathrm{pH} 8.1-8.7(\mathrm{RF} \sim 1)$, followed by sandy loam texture ( $\mathrm{RF} \sim 0.92)$, CNDVI range 4.0-4.2 ( $\mathrm{RF} \sim 0.57)$, soil $\mathrm{N}$ of $810-1000 \mathrm{mg} / \mathrm{kg}(\mathrm{RF} \sim 0.54)$ and soil EC between 310 and $460 \mu \mathrm{S} / \mathrm{m}(\mathrm{RF} \sim 0.41)$.

\section{Predicted potato yield map}

The resultant predicted potato yield map was found to be similar to that generated from the actual yield data (Figure 5). The quantitative distribution of yields generated from the tendency map (high-yield zone in particular) showed noticeable spatial correspondence to high yield (41-43 tonne/ha) in the actual yield $\left(Y_{\mathrm{A}}\right)$ map (Figure 4$)$.

Since RF represents the association weight of each class within a single factor, eq. (3) was used to find PR for all factors. As shown in Table 4, PR was calculated as the difference between minimum and maximum classes within a specific factor divided by the least minimum class of all factors. It was observed that soil $\mathrm{pH}$ was the factor with the highest association, followed by soil texture. In case of soil texture, a sandy loam class produced 
Table 3. Extraction of frequency ratio (FR) and relative frequency (RF)

\begin{tabular}{|c|c|c|c|c|c|c|c|}
\hline Factor & Factor class & $\begin{array}{l}\text { No. of } \\
\text { points }\end{array}$ & $\%$ & $\begin{array}{l}\text { Class area } \\
\left(\times 7.29 \mathrm{~m}^{2}\right)\end{array}$ & $\%$ & FR & $\mathrm{RF}$ \\
\hline \multirow[t]{4}{*}{ CNDVI } & $3.3-3.6$ & 44 & 26.09 & 15,391 & 33.88 & 0.77 & 0.25 \\
\hline & $3.7-3.9$ & 37 & 21.74 & 16,737 & 36.84 & 0.59 & 0.19 \\
\hline & $4.0-4.2$ & 88 & 52.17 & 13,302 & 29.28 & 1.78 & 0.57 \\
\hline & Sum & 168 & 100.00 & 45,430 & 100.00 & 3.14 & 1.00 \\
\hline \multirow[t]{3}{*}{ Texture } & Loam & 22 & 13.04 & 28,055 & 61.77 & 0.21 & 0.08 \\
\hline & Sandy loam & 146 & 86.96 & 17,366 & 38.23 & 2.27 & 0.92 \\
\hline & Sum & 168 & 100.00 & 45,421 & 100.00 & 2.49 & 1.00 \\
\hline \multirow[t]{4}{*}{$\mathrm{EC}(\mu \mathrm{S} / \mathrm{cm})$} & $310-460$ & 51 & 30.43 & 11,921 & 26.24 & 1.16 & 0.41 \\
\hline & $470-610$ & 95 & 56.52 & 23,668 & 52.10 & 1.08 & 0.38 \\
\hline & $620-760$ & 22 & 13.04 & 9841 & 21.66 & 0.60 & 0.21 \\
\hline & Sum & 168 & 100.00 & 45,430 & 100.00 & 2.85 & 1.00 \\
\hline \multirow[t]{4}{*}{ N (mg/kg) } & $830-1000$ & 110 & 65.22 & 19,546 & 43.02 & 1.52 & 0.54 \\
\hline & $1100-1200$ & 51 & 30.43 & 12,289 & 27.05 & 1.13 & 0.40 \\
\hline & $1300-1400$ & 7 & 4.35 & 13,595 & 29.93 & 0.15 & 0.05 \\
\hline & Sum & 168 & 100.00 & 45,430 & 100.00 & 2.79 & 1.00 \\
\hline \multirow[t]{4}{*}{$\mathrm{pH}$} & $5.7-7.2$ & 0 & 0.00 & 624 & 1.37 & 0.00 & 0.00 \\
\hline & $7.3-8.0$ & 0 & 0.00 & 2061 & 4.54 & 0.00 & 0.00 \\
\hline & $8.1-8.7$ & 168 & 100.00 & 42,745 & 94.09 & 1.06 & 1.00 \\
\hline & Sum & 168 & 100.00 & 45,430 & 100.00 & 1.06 & 1.00 \\
\hline
\end{tabular}

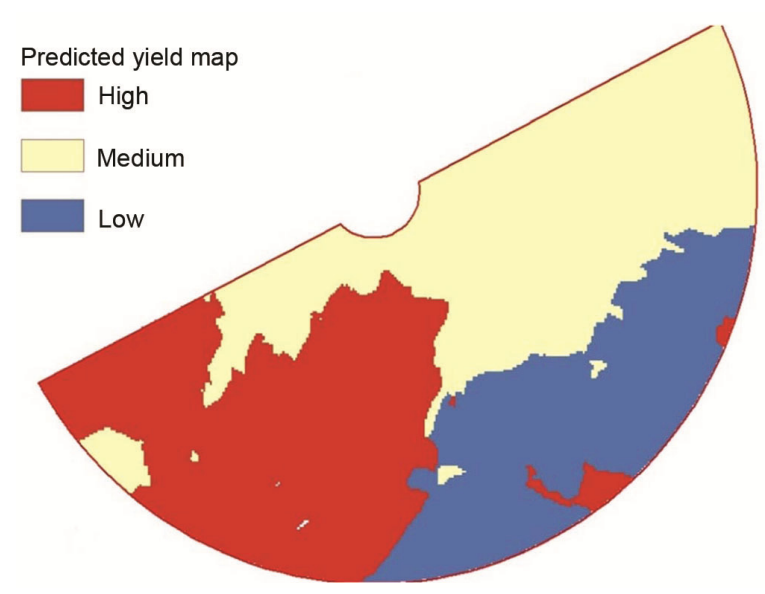

Figure 5. The predicted yield $\left(Y_{\mathrm{P}}\right)$ map.

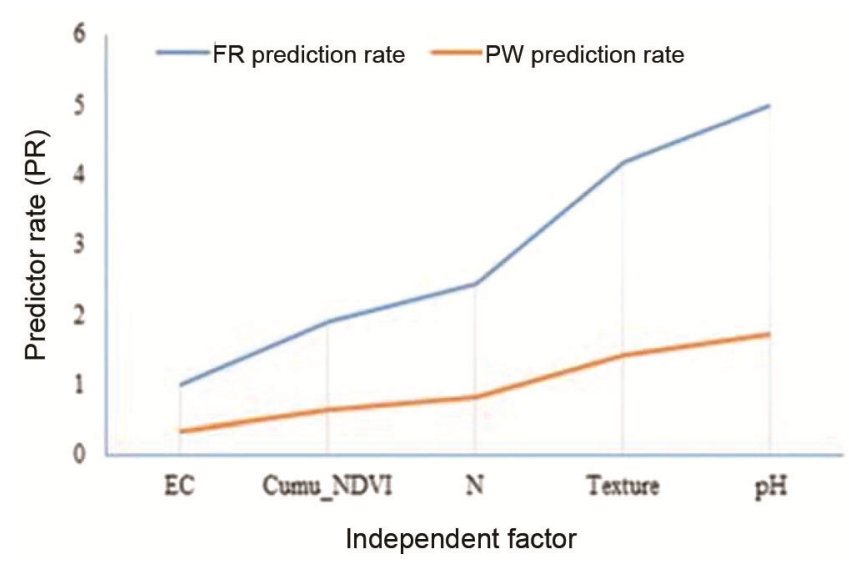

Figure 6. Status of factors that contribute to higher potato yield. the highest RF of high yield association, in agreement with previous studies that assure the validity of sandy loam in producing relatively high potato yields ${ }^{37}$. In this study, soil $\mathrm{pH}$ found to be an effective parameter in the optimization of high yield zones with PR rate of 1.0. This is contradictory to the study of Waterer ${ }^{38}$, where potato tends to yield more in less alkaline soils. However, this can be justified because all of the used training points of high yield were covered by one class of $\mathrm{pH}(8.1-8.7$ with $\mathrm{RF}$ of 1.00). The class imbalance in soil $\mathrm{pH}$ resulted in soil texture as the most effective independent parameter in yield variability ${ }^{38}$. This is further supported by a study of Redulla et $\mathrm{al}^{39}$, who concluded that soil texture components (sand, silt, clay) had a stronger influence on yield than the measured soil chemical properties.

Table 5 shows the results of alternative comparison $\mathrm{PW}$ in order to measure the accuracy of PR generated from FR, where the plot of PR achieved by the associating factors was supported by PW comparison (Figure 6). In case of individual YTFs, the results indicated that soil $\mathrm{pH}$ was a better indicator for the prediction of highyield tendency zones (with a prediction rate of 5.0). Whereas soil texture, soil N, CNDVI and soil EC had prediction rates of $4.2,2.5,1.9$ and 1.0 respectively. It can be observed from the trends that both methods produce similar weight factors, with a slight reduction in PW values. In fact, vegetation status appeared to have less influence on both predictors compared to $\mathrm{pH}$ and soil texture, where prediction rates of 1.9 and 0.65 calculated by PR and PW respectively, could be attributed to the influential effect of soil attributes on tuber crops. 
Table 4. Prediction rate calculation from FR

\begin{tabular}{lcccc}
\hline Factor & Minimum RF & Maximum RF & Maximum - minimum & $\begin{array}{c}\text { (Maximum - minimum) } \\
\text { - Minimum PR }\end{array}$ \\
\hline CNDVI & 0.19 & 0.57 & 0.38 & 1.9 \\
Texture & 0.08 & 0.92 & 0.84 & 4.2 \\
EC $(\mu \mathrm{S} / \mathrm{cm})$ & 0.21 & 0.41 & 0.20 & 0.20 \\
$\mathrm{~N}(\mathrm{mg} / \mathrm{kg})$ & 0.05 & 0.54 & 0.49 & 1 \\
$\mathrm{pH}$ & 0.00 & 1.00 & 1.00 & 5 \\
\hline
\end{tabular}

Table 5. Pairwise comparative analysis of yield tendency factors

\begin{tabular}{|c|c|c|c|c|c|c|c|}
\hline \multicolumn{8}{|c|}{ Ratio calculation } \\
\hline \multirow[t]{2}{*}{ PR } & & 1.90 & 4.20 & 1.00 & 2.45 & 5.00 & \\
\hline & Predictors & CNDVI & Texture & $\mathrm{EC}$ & $\mathrm{N}$ & $\mathrm{pH}$ & \\
\hline 1.90 & CNDVI & 1.00 & 0.45 & 1.90 & 0.78 & 0.38 & \\
\hline 4.20 & Texture & 2.21 & 1.00 & 4.20 & 1.71 & 0.84 & \\
\hline 1.00 & $\mathrm{EC}$ & 0.53 & 0.24 & 1.00 & 0.41 & 0.20 & \\
\hline 2.45 & $\mathrm{~N}$ & 1.29 & 0.58 & 2.45 & 1.00 & 0.49 & \\
\hline \multirow[t]{2}{*}{5.00} & $\mathrm{pH}$ & 2.63 & 1.19 & 5.00 & 2.04 & 1.00 & \\
\hline & Sum & 7.66 & 3.46 & 14.55 & 5.94 & 2.91 & \\
\hline \multicolumn{8}{|c|}{ Weight calculation } \\
\hline \multirow[t]{2}{*}{ PR } & & 1.90 & 4.20 & 1.00 & 2.45 & 5.00 & PW \\
\hline & Predictors & CNDVI & Texture & $\mathrm{EC}$ & $\mathrm{N}$ & $\mathrm{pH}$ & \\
\hline 1.90 & CNDVI & 0.13 & 0.13 & 0.13 & 0.13 & 0.13 & 0.65 \\
\hline 4.20 & Texture & 0.29 & 0.29 & 0.29 & 0.29 & 0.29 & 1.44 \\
\hline 1.00 & $\mathrm{EC}$ & 0.07 & 0.07 & 0.07 & 0.07 & 0.07 & 0.34 \\
\hline 2.45 & $\mathrm{~N}$ & 0.17 & 0.17 & 0.17 & 0.17 & 0.17 & 0.84 \\
\hline \multirow[t]{2}{*}{5.00} & $\mathrm{pH}$ & 0.34 & 0.34 & 0.34 & 0.34 & 0.34 & 1.72 \\
\hline & Sum & 1.00 & 1.00 & 1.00 & 1.00 & 1.00 & \\
\hline
\end{tabular}

PW, Pairwise weight.
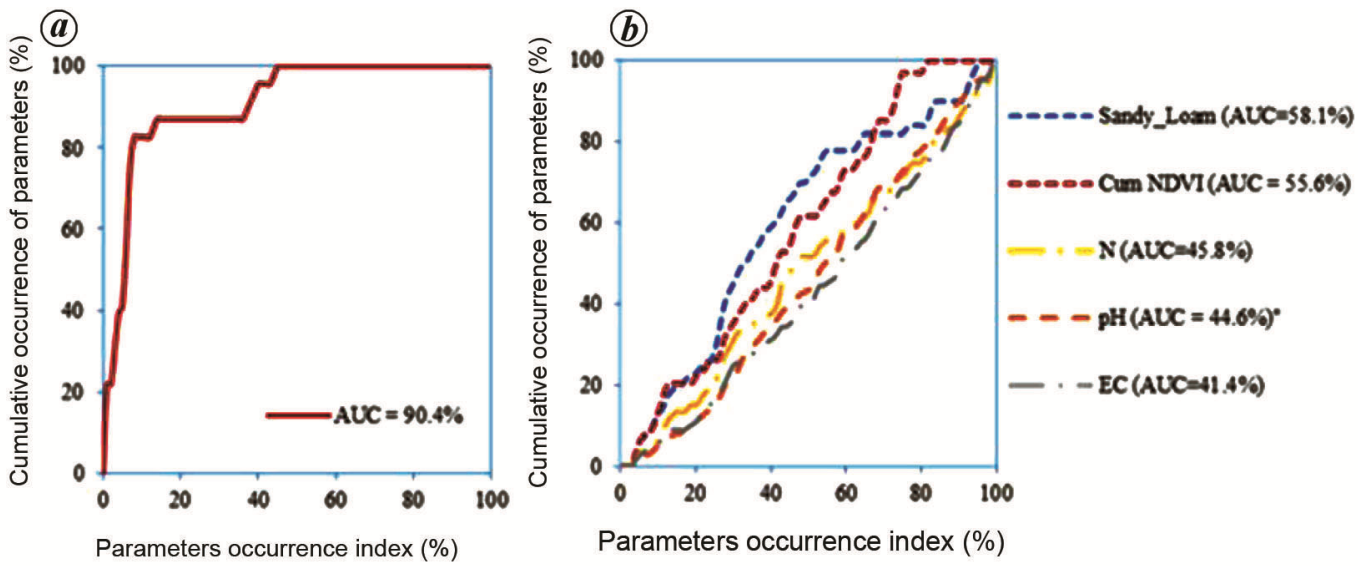

Figure 7. Comparison of the AUC (the areas under the curve) for the prediction of high yield zones with 'Parameters Occurrence Index': $\boldsymbol{a}$, Cumulative response of all the studied yield tendency factors (YTFs); $\boldsymbol{b}$, The independent response of YTFs to high yield class.

\section{Model validation}

It was observed that the developed high-yield zones accurately (AUC $\sim 90 \%$ ) represent the actual yield map (Figure $7 a$ ). However, AUC analysis was weak/low (41$58 \%$ ) for independent YTFs (Figure $7 b$ ). Significant cor- relation was observed with $\mathrm{pH}$ (AUC $\sim 44.6 \%$ ). In case of other YTFs, the obtained correlations were characterized as moderate to weak/low, and arranged in ascending order as $\mathrm{EC}>\mathrm{N}>\mathrm{CNDVI}>$ texture. The soil texture (sandy loam) produced relatively highest tendency for yield prediction $(\mathrm{AUC} \sim 58.1 \%$ ), followed by CNDVI 
with AUC value of $55.6 \%$ (Figure $7 \mathrm{~b}$ ). This might be due to the admixed association caused by the nonrepresentative classes at each factor map, as the maps were rejected during the reclassification process and subsequently for AUC calculation. Although AUC ranged from 50 to 60 , which can be interpreted as weak values, the failure of the separated variables is also a positive finding because any independent variable has classes that associate negatively in high-yield zoning. Conversely, soil $\mathrm{N}, \mathrm{EC}$ and $\mathrm{pH}$ were observed to have almost equal prediction capacities.

\section{Conclusion}

Soil parameters and NDVI are considered as key components in identifying high-yield tendency zones in agricultural fields. In this study, the spatial correlation was evaluated using BFR between the actual yield map of potato crop (as a dependent factor) and the crop cumulative NDVI, soil N, EC, $\mathrm{pH}$ and texture maps (as independent factors). The summarized conclusions are as follows:

- The calculated prediction rate of the independent factors highlighted that soil $\mathrm{pH}$ had the highest association with high-yield zones (AUC 5.0), followed by soil texture, N, CNDVI and EC, with rates of 5.0, 4.2, 2.45, 1.9 and 1.0 respectively.

- The generated map revealed high prediction accuracy of high-yield areas compared to actual yield $\left(Y_{\mathrm{A}}\right)$, supported by AUC value of $90 \%$.

- The resultant accuracy assessment of the independently applied factors to predict yield showed low values, ranging from $41 \%$ to $58 \%$.

Conflict of interests: The authors declare no conflict of interest.

1. Jin, J. and Jiang, C., Spatial variability of soil nutrients and sitespecific nutrient management in the P.R. China. Comput. Electron. Agric., 2002, 36(2-3), 165-172; https://doi.org/10.1016/S01681699(02)00099-6.

2. Cerri, C. E. P. et al., Assessment of soil property spatial variation in an Amazon pasture: basis for selecting an agronomic experimental area. Geoderma, 2004, 123(1-2), 51-68; https://doi.org/ 10.1016/j.geoderma.2004.01.027.

3. Srinivasan, A. (ed.), Precision agriculture: an overview. In Handbook of Precision Agriculture Principles and Applications, CRC Press, Taylor and Francis, London, UK, 2006, pp. 3-15; ISBN 9781560229551.

4. Vauclin, M., Vieira, S. R., Bernard, R. and Hatfield, R., Spatial variability of surface temperature along two transects of a bare soil. Water Resour. Res., 1982, 18(6), 1677-1686; https://doi.org/ 10.1029/WR018i006p01677.

5. Mulla, D. J., Mapping and managing spatial patterns in soil fertility and crop yield. In Soil Specific Crop Management (eds Robert, P. C., Larson, W. E. and Rust, R.), American Society of Agronomy, Madison, WI, 1993, pp. 15-26.
6. Vieira, S. R., Millete, J., Clark, T. G. and Dan, R. W., Handbook for geostatistical analysis of variability in soil and climate data. Topicos Ci. Solo, 2002, 2, 1-45.

7. Rabbi, S. M. F., Roy, B. R., Miah, M. M., Amin, M. S. and Khandakar, T., Spatial variability of physical soil quality index of an agricultural field. Appl. Environ. Soil Sci., 2014, 379012; http://dx.doi.org/10.1155/2014/379012.

8. Tola, E., Al-Gaadi, K. A., Madugundu, R., Zeyada, A. M., Kayad, A. G. and Biradar, C. M., Characterization of spatial variability of soil physicochemical properties and its impact on Rhodes grass productivity. Saudi J. Biol. Sci., 2017, 24(2), 421-429; https://doi. org/10.1016/j.sjbs.2016.04.013.

9. Matheron, G., The theory of regionalized variables and its application. Les Cahiers du Centre de Morphologie Mathematique, Fontainebleau. The Ecole Nationale Superieure des Mines de Paris, 1971, 5, 211; http://cg.ensmp.fr/bibliotheque/public/MATHERON Ouvrage 00167.pdf

10. Rockstrom, J., Barron, J., Brouwer, J., Galle, S. and De Rouw, A., On-farm spatial and temporal variability of soil and water in pearl millet cultivation. Soil Sci. Soc. Am. J., 1997, 63(5), 1308-1319; doi:10.2136/sssaj1999.6351308x.

11. Gatson, L. A., Locke, M. A., Zablotowicz, R. M. and Reddy, K. N., Spatial variability of soil properties and weed populations in the Mississippi Delta. Soil Sci. Soc. Am. J., 2001, 65(2), 449-459; doi:10.2136/sssaj2001.652449x.

12. Vieira, S. R., Spatial variability of clay content, silt content and chemical properties within an experimental plot of a dusky red latosol in Campinas, State of Sao Paulo, Brazil. Bragantia, 1997, 56(1), 181-190; http://dx.doi.org/10.1590/S0006-87051997000100019.

13. Chung, S. O., Sung, J. H., Sudduth, K. A., Drummond, S. T. and Hyun, B. K., Spatial variability of yield, chlorophyll content, and soil properties in a Korean rice paddy field. In Proceedings of the Fifth International Conference on Precision Agriculture (eds Robert, P. C., Rust, R. H. and Larson, W. E.), American Society of Agronomy, Madison, WI, USA, 2001, pp. 1-14.

14. Fulton, J. P., Wells, L. G., Shearer, S. A. and Barnhisel, R. I., Spatial variation of soil physical properties: a precursor to precision tillage. In American Society of Agricultural Engineers, Paper No. 961002, International Meeting, Phoenix, Arizona, USA, 1418 July 1996.

15. Wells, L. G., Shearer, S. A., Fulton, J. P. and Murdock, L. W., Assessment of remote sensing for implementation of precision tillage. In American Society of Agricultural Engineers, Paper No. 001084, International Meeting, Milwaukee, WI, USA, 9-12 July 2000.

16. Mzuku, M., Khosla, R., Reich, R., Inman, D., Smith, F. and MacDonald, L., Spatial variability of measured soil properties across site-specific management zones. Soil Sci. Soc. Am. J., 2005, 69(5), 1572-1579; doi:10.2136/sssaj2005.0062.

17. Inman, D. J., Khosla, R. and Westfall, D. G., Nitrogen uptake across site-specific management zones in irrigated corn production systems. Agron. J., 2005, 97(1), 169-176; doi:10.2134/ agronj2005.0169.

18. Cambardella, C. A. et al., Field-scale variability of soil properties in central Iowa soils. Soil Sci. Soc. Am. J., 1994, 58(5), 15011511; doi:10.2136/sssaj1994.03615995005800050033x.

19. Marques Jr, Jose, R. B. S. and Pereira, G. T., Variabilidade espacial de propriedades químicas e físicas de latossolos em áreas de cerrado sob cultivo de café, em Patrocínio, MG. In $O$ estado-daarte da agricultura de precisão no Brasil, Capitulo III-Mapeamento da Produtividade e de Atributos de Solos e de Plantas (ed. Balastreire, L. A.), Piracicaba, ESALQ, 2000, pp. 105-112.

20. Khosla, R., Fleming, K., Delgado, J. A., Shaver, T. M. and Westfall, D. G., Use of site-specific management zones to improve nitrogen management for precision agriculture. J. Soil Water Conserv., 2002, 57(6), 513-518. 
21. Fraisse, C. W., Sudduth, K. A., Kitchen, N. R. and Fridgen, J. J., Use of unsupervised clustering algorithms for delineating within field management zones. In American Society of Agricultural Engineers, Paper No. 993043, International Meeting, Toronto, Ontario, Canada, 18-21 July 1999.

22. Lee, S., Application and verification of fuzzy algebraic operators to landslide susceptibility mapping. Environ. Geol., 2007, 52(4), 615-623.

23. Pradhan, B., Landslide susceptibility mapping of a catchment area using frequency ratio, fuzzy logic and multivariate logistic regression approaches. J. Indian Soc. Remote Sensing, 2010, 38(2), 301320; https://doi.org/10.1007/s12524-010-0020-z.

24. Lepore, C., Kamal, S. A., Shanahan, P. and Bars, R. L., Rainfallinduced landslide susceptibility zonation of Puerto Rico. Environ. Earth Sci., 2012, 66(6), 1667-1681; doi:10.1007/s12665-0110976-1.

25. Mohammady, M., Pourghasemi, H. R. and Pradhan, B., Landslide susceptibility mapping at Golestan Province, Iran: a comparison between frequency ratio, Dempster-Shafer, and weights-ofevidence models. J. Asian Earth Sci., 2012, 61, 221-236; https://doi.org/10.1016/j.jseaes.2012.10.005.

26. Hassaballa, A. A., Althuwaynee, O. F. and Pradhan, B., Extraction of soil moisture from RADARSAT- 1 and its role in the formation of the 6 December 2008 landslide at Bukit Antarabangsa, Kuala Lumpur. Arab. J. Geosci., 2014, 7(7), 2831-2840; https://doi.org/ 10.1007/s12517-013-0990-6.

27. Althuwaynee, O. F., Pradhan, B. and Lee, S., Application of an evidential belief function model in landslide susceptibility mapping. Comput. Geosci., 2012, 44, 120-135; https://doi.org/10. 1016/j.cageo.2012.03.003.

28. Suzen, M. L. and Vedat, D. A., A comparison of the GIS based landslide susceptibility assessment methods: multivariate versus bivariate. Environ. Geol., 2004, 45(5), 665-679; https://doi.org/ 10.1007/s00254-003-0917-8.

29. Al-Faifi, H. J. A., Evaluation of groundwater resources in Wajid aquifer in Wadi Dawasir area Southern Saudi Arabia using computer simulation. M Sc thesis, Department of Geology, College of Science, King Saud University, Kingdom of Saudi Arabia, 2005, pp. 3-9.

30. Al-Gaadi, K. A. et al., Prediction of potato crop yield using precision agriculture techniques. PLoS ONE, 2016, 11(9), e0162219; https://doi.org/10.1371/journal.pone.0162219.

31. Lynch, J. M. and Barbano, D. M., Kjeldahl nitrogen analysis as a reference method for protein determination in dairy products. J. AOAC Int., 1999, 82, 1389-1398.
32. Bouyoucos, G. J., A recalibration of the hydrometer method for making mechanical analysis of soils. Agron. J., 1951, 43(9), 434438; doi:10.2134/agronj1951.00021962004300090005x.

33. Rouse Jr, J. W., Haas, R. H., Schell, J. A. and Deering, D. W., Monitoring vegetation systems in the Great Plain with ERTS. In Third ERTS-1 Symposium-volume 1: Technical Presentations (eds Fraden, S. C., Marcanti, E. P. and Becker, M. A.), NASA SP-351, Washington DC, USA, 1974, pp. 309-317.

34. Lee, S., Application of logistic regression model and its validation for landslide susceptibility mapping using GIS and remote sensing data. Int. J. Remote Sensing, 2005, 26(7), 1477-1491.

35. Sujatha, E. R., Rajamanickam, V., Kumaravel, P. and Saranathan, E., Landslide susceptibility analysis using probabilistic likelihood ratio model - a geospatial-based study. Arab. J. Geosci., 2013, 6(2), 429-440; https://doi.org/10.1007/s12517-011-0356-X.

36. Althuwaynee, O. F., Pradhan, B., Park, H. J. and Lee, J. H., A novel ensemble bivariate statistical evidential belief function with knowledge-based analytical hierarchy process and multivariate statistical logistic regression for landslide susceptibility mapping. Catena, 2014, 114, 21-36; https://doi.org/10.1016/j.catena. 2013.10.011.

37. Allaire, S. E., Cambouris, A. N., Lafond, J. A., Lange, S. F., Pelletier, B. and Dutilleul, P., Spatial variability of potato tuber yield and plant nitrogen uptake related to soil properties. Agron. J., 2014, 106(3), 851-859.

38. Waterer, D., Impact of high soil $\mathrm{pH}$ on potato yields and grade losses to common scab. Can. J. Plant Sci., 2002, 82, 583-586.

39. Redulla, C. A., Davenport, J. R., Evans, R. G., Hattendorf, M. J., Alva, A. K. and Boydston, R. A., Relating potato yield and quality to field scale variability in soil characteristics. Am. J. Potato Res., 2002, 79(5), 317-323.

ACKNOWLEDGEMENTS. We are grateful to the Deanship of Scientific Research, King Saud University, Riyadh, Saudi Arabia for funding this study through the Vice Deanship of Scientific Research Chairs. We also thank Mohammed Edrris, Ahmed Alameen and Haroon Faroog for assistance in the field, and the staff of Saudi Agricultural Development Company (INMA), Wadi-Ad-Dawasir, Saudi Arabia for co-operation and support while carrying out field work.

Received 10 November 2019; accepted 23 July 2020

doi: $10.18520 / \mathrm{cs} / \mathrm{v} 119 / \mathrm{i} 6 / 992-1000$ 